\title{
Correction to: Shen-Zhi-Ling oral liquid ameliorates cerebral glucose metabolism disorder in early AD via insulin signal transduction pathway in vivo and in vitro
}

Gaofeng Qin ${ }^{1,2 \dagger}$, Yunfang Dong ${ }^{1 \dagger}$, Zhenhong Liu ${ }^{1,3 \dagger}$, Zhuoyan Gong ${ }^{1,4}$, Chenyan Gao ${ }^{1}$, Mingcui Zheng ${ }^{1}$, Meijing Tian', Yannan He ${ }^{1}$, Liqun Zhong ${ }^{1 *}$ and Pengwen Wang ${ }^{1 *}$

\section{Correction to: Chinese Medicine (2021) 16: 128}

https://doi.org/10.1186/s13020-021-00540-0

Following publication of the original article [1], the authors identified an error in the column DAPI of Fig. 11 (A1). The correct Fig. 11 (Fig. 11) is given in this erratum.

The original article has been corrected.

*Correspondence: zhongliqun@sina.com; pw_wang@163.com to the material. If material is not included in the article's Creative Commons licence and your intended use is not permitted by statutory regulation or exceeds the permitted use, you will need to obtain permission directly from the copyright holder. To view a copy of this licence, visit http://creativecommons.org/licenses/by/4.0/. The Creative Commons Public Domain Dedication waiver (http://creativecommons.org/publicdomain/zero/1.0/) applies to the data made available in this article, unless otherwise stated in a credit line to the data. 


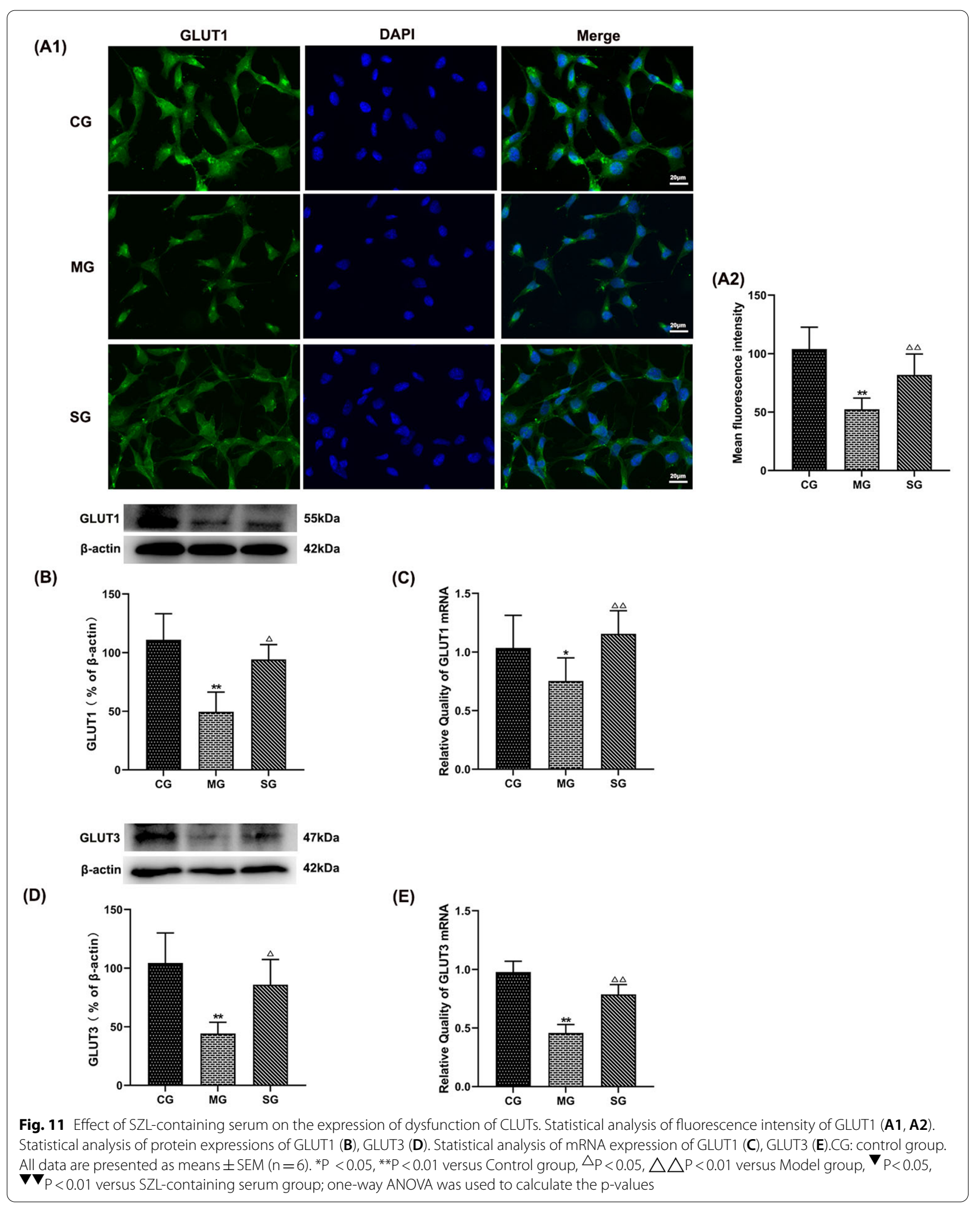




\section{Author details}

${ }^{1}$ Key Laboratory of Chinese Internal Medicine of Ministry of Education and Beijing, Dongzhimen Hospital, Beijing University of Chinese Medicine (BUCM), Haiyuncang No. 5 in Dongcheng District, Beijing, China. ${ }^{2}$ Binzhou Medical University Hospital, Shandong, China. ${ }^{3}$ Institute for Brain Disorders, Beijing University of Chinese Medicine (BUCM), Beijing, China. ${ }^{4}$ Beijing Prominion Publishing Co. Ltd, Beijing, China.

Published online: 31 December 2021

\section{Reference}

1. Qin G, Dong Y, Liu Z, Gong Z, Gao C, Zheng M, Tian M, He Y, Zhong L, Wang P. Shen-Zhi-Ling oral liquid ameliorates cerebral glucose metabolism disorder in early AD via insulin signal transduction pathway in vivo and in vitro. Chin Med. 2021;16:128.

\section{Publisher's Note}

Springer Nature remains neutral with regard to jurisdictional claims in published maps and institutional affiliations.

- fast, convenient online submission

- thorough peer review by experienced researchers in your field

- rapid publication on acceptance

- support for research data, including large and complex data types

- gold Open Access which fosters wider collaboration and increased citations

- maximum visibility for your research: over 100M website views per year

At BMC, research is always in progress.

Learn more biomedcentral.com/submissions 